\title{
Racial Oppression, Black Consciousness and the Quest for Freedom in Peter Abrahams' Mine Boy (1946)
}

\author{
Babacar Diakhaté \\ Laboratoire d'Études africaines et postcoloniales, Université Cheikh Anta Diop, Dakar, Sénégal \\ diakhatebabacar83@hotmail.fr
}

\section{Abstract}

The white South African capitalist system deprived the rural population of their lands. This deprivation of their cultivating lands engendered the displacement of the proletariat class to the city to find a better life. In 1946, Peter Abrahams released Mine Boy to denounce the exploitation and oppression of the blacks by white people. This article aims at castigating the inhuman treatment reserved for Xuma, a village rural boy who goes to Johannesburg to improve his economic situation in the mine. Xuma's predicaments and Johannes and Chris' deaths in the mines illustrate the brutal attitudes of the white bosses towards their mineworkers. The rising consciousness of the mineworkers leads them to a perpetual liberation struggle that finally ends in their historical freedom.
Keywords

racial oppression; black consciousness the quest for freedom Peter Abrahams' Mne Boy (1946)

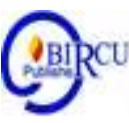

\section{Introduction}

With the advent of white colonizers in South Africa, many black South Africans were transformed into landless rural proletarians. Indeed, the native land act of 1913 reserved 93 per cent of the total South African territory for the white colonizers. This resulted in driving many blacks to seek jobs in the mines. In 1946, Peter Abrahams published Mine Boy to denounce the social injustice that prevailed in this part of the continent. The writer is inspired by the history of his own father who used to be a mineworker and finally died when Abrahams was younger. Apart from Mine Boy, the author has also published Tell Freedom (1954) and Song of the City (1945).

In Mine Boy, Peter Abrahams portrays the Apartheid system through Xuma, a rural person who comes in Johannesburg to eke out a living. After his stay in Malay Camp, Xuma shifts to Vrededrop to live in his own house. The aim of this article is to depict the colonial capitalist system through the hard living condition of black people, the injustice and discrimination they undergo during Apartheid. The first section lays emphasis on individual experiences through Abrahams' black characters and the second part focuses on all the ways and means adopted by the oppressed to lead a liberation struggle. The final section brings to light the achievements of the black community after their struggles.

\section{Review of Literatures}

\subsection{Daddy and Xuma as victims of Apartheid System}

Black people's hard living conditions during apartheid are characterized by darkness and danger. Daddy and Xuma are innocent characters who undertake a long journey to Johannesburg to find a better living condition. They are finally disillusioned by the unhuman conditions of work they are subjected to. Daddy's character is very important in 
the novel. He is the first victim of the system that prevails in his local. He cannot prevent the system from existing but he has his own method to avoid it. Indeed, he spends all his time drinking illicit liquid, he is never sober. His keen on beer is seen when he bumps into Xuma who wants to know Leah's new place. Daddy accepts to show him leah's new address provided that he gives him a bottle of beer. The presence of beer is very important in Daddy's life during his stay in Johannesburg. Firstly, he is never sober, and secondly he dies after drinking beer and finally hit by a car. Drinking beer is an alibi to forget the oppression. Leah is the first person to suffer from Daddy's death. She is much more affected by Daddy's death than by her parents'. The farther readers go into the novel, the harsher the system becomes with Xuma.

Darkness, danger and fear are the evils that illustrate Xuma's misfortune in general. His solitude and fear overwhelm him and prevent him from escaping. The knife that Dladla handles toward Xuma shows the level of criminality in the city.

\subsection{Identity Crisis}

The portrait of the black middle-class as represented by Eliza and Dr Mini must be examined. Eliza is a teacher who is torn between her love for Xuma and other aspirations. She asserts:

...But inside me there is something wrong. And it is because I want the thing of the white people. I want to be like the white people and go where they go and do the things they do and I am black. I cannot help it. Inside me I am not black and I do want to be a black person.( Abrahams, 1946:60).

Eliza cannot identify herself with her community. She wants to get the things the white person possesses. Because of complexity, she is not proud of her identity and underestimates herself in front of the white people. Like Daddy and Xuma, Eliza is also a victim of the system. Her yearning for the things of the white man nearly drove her crazy. She is in love with Xuma, but because of the color of his skin, she does not want to kiss him. She prefers a white man to a black one. Her western education also provides her with petit-bourgeois aspiration and causes her desire to identify with a white culture. She is alienated from the black proletarian society.

Eliza displays the inevitable contradictions of an educated black person in a society where the vast majority of her people do not have access to education. Fortunately for Xuma, he does not experience identity crisis like Eliza for not being at school. Eliza's refusal to kiss Xuma is not related to hatred. She is not at the same level as her community. And Xuma's incapacity to subjugate and conquer Eliza is due to his lack of western education. As long as the system exists Eliza still yearns for the white people things she never affords.

Identity crisis is recurrent in the 21st century African novel. In Amma Darko's Beyond the Horizon, No Violet Bulawayo's We Need New Names, Chika Unigwe's On Black Sisters Street, Sefi Atta's News from Home, Chimamanda Ngozi Adichie's Half of a Yellow Sun and most of Buchi Emecheta's writings such as the Joys of Motherhood and the Family, etc; all address identity crisis through their protagonists like, Mara, Alice, Olanna, Master, Oshia, etc. Their authors display the hard living conditions that their characters are exposed abroad. The hardships they undergo lead them to change their authentic identity in order to look like the white man.

In Mine Boy, Eliza who comforts Xuma after Daddy's death, leaves home for a journey. Her departure brings about Xuma's loneliness and his endless memories. 


\subsection{Loneliness and Memories}

Apartheid puts Xuma in everlasting memories. This sad situation and Eliza's departure put Xuma in solitude. He thinks about the nice moments he spends with Eliza. He walks in the street without aim. Eliza would talk to him, cook good meals for him too. They would stroll in the street. Padddy leads Xuma to the street and shows him where he lives.

Paddy and Xuma sit down while the woman comes in with three glasses. They raise their glasses and cheer Xuma. Whatever they do, Xuma keeps on thinking about Eliza. The wind of loneliness blowing in Paddy's house reveals what Eliza represents in Xuma's life.

Leah is a stout and courageous woman who ekes out a living by selling illicit brew. Unfortunately, Dladla does not get on well with Leah and denounces her to the police. Leah is always trapped by the police. Finally, Leah's arrest with illicit liquid costs her a ninemonth imprisonment. After her arrest, Eliza recommends Maisy to take care of Ma Plank who is a mother figurer.

Xuma wants to go along with Leah to the police. He admits we have all together (Abrahams, 1946 :). Consequently, Xuma and Ma Plank suffer from Leah's absence. The place has become empty and quiet. Daddy dies because of the system he cannot face, Eliza leaves forever because she wants the things of the white men. Moreover, Leah is arrested by the police. These are the factors of Xuma's loneliness.

Xuma goes back to the mine where he meets again Paddy and reports on him all the events that have taken place and how his people are directly affected. Paddy's pieces of advice to Xuma epitomize his sense of humanism.

\section{Discussion}

\subsection{The Human Condition}

In the context of Apartheid, the human condition is related to all the bad treatment that the white community perpetrated to the downtrodden and marginalized class represented by the black race. Frustration, suffering, misery and loneliness characterize the life of the black exploited community. In Mine Boy, Daddy's death, Xuma's illness, Eliza's loss of identity and Paddy's imprisonment inform readers of the hardships of life of blacks treated like slaves in the mines.

Hannah Arendt's The Human Condition traces the relationships between slave and master, the rulers and the ruled ones and also the different forms of governments like Monarchy, a government ruled by one person, Oligarchy, a government ruled by few, and Democracy, a government ruled by many. André Malraux's La Condition Humaine published in 1933 is in the same vein. La Condition Humaine or Man's Fate in English was translated into English twice, both translations appear in 1934 under the title The Storm in Shanghai and later Man's Estate in 1948. Malraux emphasizes the life of an individual known as Chen Ta Earth who is governed by fatality and desires to kill. In the text, the author focuses on other universal themes like suicide, sacrifice, revolt, etc.

Hannah Arendt's The Human Condition and André Malraux's Man's Fate have been echoed by Albert Camus's l'Absurde in l'Etranger and Jean- Paul Sartre's l'Existentialisme est un Humanisme, all these novels show interest in the human condition. In the former, Camus brings to light some universal human qualities like dignity, sincerity, honesty, etc through his protagonist Meursault who is alien to the society in which he lives. He does not cry during his mother's burial, and he does not regret having killed an Arab. In his essay, Sartre tackles the same issue by fighting against the social and economic classes and at the same time improves the social condition of Man. 
In Mine Boy, the white supremacy over the black community is visible in the mines. It requires sacrifice and suffering for the oppressed to get rid of their condition. The situation of the mine workers is a symbol of poverty of the black race. The economic gap between the haves represented by the whites and have-nots symbolized by the poor blacks is so huge that the latter are seen as beasts with their white shepherd. Johannes and Chris' deaths in the mine and Xuma's blood oozing from his mouth epitomize the suffering of black people in South Africa.

\subsection{Appeal to Humanism}

This appeal to humanism is very important in the rest of Xuma's life. This human attitude allows him to resume his work in the mine. However, Paddy knows that something is amiss with Xuma and asks him about his troubles. He answers: You want me to be your friend. How can I be your friend if your people do this to my people (Abrahams, 1946: 72-3). Xuma accuses the whites of being responsible for their situation. Paddy replies:

"No". You must think as a man first. You must be a man first and then be a black man. And if it is so you will understand as a black man and also as a white man. That is the right way Xuma. (Abrahams, 1946:74).

Paddy thinks that the world in which everybody sees him/ herself as a Man first without promoting any race is a world of happiness, friendship, brotherhood and solidarity. This appeal to humanism is obviously of vital importance in the struggle against racial oppression. Peter Abrahams brings into an "Africanist" ideology positive values capable of withstanding the racist designation of African life.

\subsection{Awareness and the Quest for Identity}

Xuma's own experiences make him conscious of his oppression and he gets engaged in a quest for identity. His self-confidence overwhelms him when he encounters Paddy, the white man deeply involved in the black cause. Their meeting triggers off Xuma's rising consciousness. He shifts from innocence to awareness, and undertakes hard struggles in order to improve his living condition. His maturity is his consciousness of his own self and finds it necessary to achieve freedom. This permits him to know who he really is.

However, he is not interested in his geographical, social and cultural backgrounds. The most important thing is to be seen as a true human being regardless the color of his skin. He is concerned about universal human race. The good attitude of Xuma in the mines renders him a responsible and respected person. Indeed, he is in charge of monitoring other mine boys with humanitarian style of conduct. This reversal of situation is all the more significant as it reveals Xuma's coming of age and personality. From innocence and childhood, Xuma grows into maturity and adulthood.

\subsection{Liberation Struggle}

This liberation struggle invites all the people who are fighting for human dignity and for the better living condition of the human race. Black and white workers "share a common interest" and therefore should "act together" to defeat the shared enemy. This enemy is the racist system of Apartheid. The validity of this struggle depends on Paddy, the white miner who joins Xuma and his fellow-workers in the strike against the mine bosses.

The involvement of the white man in the struggle against racism is also developed by Nadine Gordimer in My Son's Story through the characters of Sunny, Will and Annah Ploughman. They join the struggle for black dignity in South Africa. In Mine Boy and My Son's Story authors are concerned about the hard living condition of the black race during Apartheid. The bad attitude of the whites is opened out to their readers to denounce human 
exploitation. The inhumane attitude of the boss when Johannes and Chris die in an accident leaves to be desired. When the boss arrives in the mine, he considers the accident as minor. Xuma protests: we are men!!! It does not matter if our skins are black. We are not cattle to throw our lives, we are men (Abraham, 1946: 181).

As a result, they fight the system by organizing themselves. They are aware of the danger to which they are exposed in the mines. No matter what happens to them, no matter what the hard living conditions, they always promote human dignity. They all gather to dig graves in which Johannes and Chris must be buried. Paddy, a white man though, walks over to Xuma and shakes his hands saying I am a Man first Xuma (Abrahams, 1946: 81-82). Then, he turns to the other mine boys and shouts: Xuma is right! They pay you little! They don't care if you risk your lives: Why is-it so? Does not a black man feel too? Does not a black man love life too? I am with you: let them fix the place first (Abrahams, 1946: 181-182).

When Paddy asks why black workers are exploited, the answer he receives does not point an accusing finger to capitalism but a pervasive racism that fails to recognize that blacks are " human beings". As described in the passage, racism does not oppress whites. Paddy clarifies it when he shouts Is not the blood of a black man red like that of a white man? (Abrahams, 1946: 182-183).

There is no suggestion that "the problem of the whites workers are fundamentally similar" to that of blacks. There is no suggestion that Paddy, as a privileged white worker, finds any motivation of class interest in the struggle. Rather, Paddy's action signifies that the individual commitment of a white democrat to promote the liberation struggle of an oppressed group shares his privileged social status.

\subsection{After-Struggle Events}

Paddy's involvement in the struggle for black liberation leads him to jail. Xuma does not want to be free and leave Paddy in prison. Xuma notices that Paddy fights first as a man and later, as a white or a black. Xuma is very committed to go and join Paddy in prison. He says I must go. I'll not live for the disgust I'll have against myself. So I must go (Abrahams, 1946:183).

Xuma shows gratefulness, courage and dignity to Paddy .He knows that he will not be free as long as Paddy is in jail. He is very indebted to Paddy and does not want to be a coward. After the report, Xuma renews his love towards Maisy and promises to come back one day and set a family. Maisy replies that: When you come back we will live in a home where there will be much laughter and much happiness (Abrahams, 1946: 83-84). Peter Abrahams raises hope in the mindsets of black people in the racist system. He knows that blacks start a struggle for liberation that will be successful. He lets black people know that freedom is looming ahead. He puts: One by one the lights of Malay camp were turned out. One by one the lights of Vrededrop and the other dark places of Johannesburg of South Africa were turned out. (Abrahams, 1946:84-85).

The light he is alluding to is the day of truth. It is when black people are aware of their rights and fight for them. Darkness symbolizes the period of racial oppression and black consciousness is the achievements of freedom. After a long fight for liberation, South Africa was compensated with the organization of the 19th soccer world cup.

A country that was characterized by racial segregation and dominated by whites gathered all the races in the world. This choice of the world football officials was not at random. South Africa left from afar to be what it is today. However, racial discrimination is not totally eradicated in South Africa as revealed by J. M. Coetzee in Disgrace (2013) through his characters the white Professor David and his young black mistress student, Melanie during the act of rape. 


\section{Conclusion}

A South African capitalist system has deprived the proletarian class of their rural lands. This deprivation of their lands, as their places of works, pushes the black men to migrate to the city to find a better life. Inspired by the tragic life of his father who died in the mines, Peter Abrahams publishes Mine Boy to depict the social injustice that prevails in South Africa. In Mine Boy Abrahams blends fiction and reality to denounce the hard living conditions of the black class proletariat. This article has revealed the individual experiences of the mine laborer, as shown through Xuma in the mine. This system of Apartheid, and particularly of capitalism, triggers off the deaths of Johannes and Chris in an accident in the eyes of their white bosses. Therefore, Blacks' awareness of their oppression by the whites is the beginning of their liberation struggle. The implication of white humanists such as Paddy results in the achievements of their freedom.

\section{References}

ABRAHAMS, Peter (1946). Mine Boy, London: Heinemann.

....Tell Freedom. (1954). Faber \&Faber (16mars 1981).

.....The Song of the City. (1945). Dorotthy Crisp.

ADICHIE C. Ngozi. (2009). Half of a Yellow Sun. London: Fourth Estate.

ARENTH, Hannah. ( 1958).The Human Condition, Chicago: University of Chicago Press.

......., The Origins of Totalitarianism. (1951). New York: Harcourt Brace Jovanovich, 1951.Third edition with new prefaces, 1973.

ATTA, Sefi. (2010). News from Home, Interlink book.

BULAWAYO, No Violet (2013). We Need New Names. New York: Hachette Book Group.

CAMUS, Albert. (1942). L'Etranger, Folio Essais, Gallimard.

COETZEE, M. J. (2013). Disgrace. Penguin Books.

EMECHETA, Buchi. (1979). the Joys of Motherhood, USA, George Braziller.

...,The Family. (1989). London: Heinemann.

...,The New Tribe. (2000). African writers series, London: Heinemann.

GORDIMER, Nadine. (1990). My Son's Story. Hardback \& Paperback.

MALRAUX, André. (1933). the Human Condition, New York: Harrison Smith and Robert. Translated under the tile Man's Fate by Haakon Chevalier, New York: Modern Library, in 1934 and Storm in Shanghai; Methiren 1934 reissued as Man's Estate in 1948.

SARTRE, Jean Paul. (1946). L'Existentialisme est un Humanisme, Folio Essais, Editions Nagel.

UNIGWE, Chika (2009) Black Sisters Street. Random House: New York. 